\title{
Analisis Kemampuan Komunikasi Matematis Siswa ditinjau dari Self-Concept
}

\section{Siti Maryam Sari ${ }^{1}$ and Heni Pujiastuti ${ }^{2}$}

1,2Jurusan Pendidikan Matematika Pascasarjana Universitas Sultan Ageng Tirtayasa, Banten

Corresponding Author: maryam.sari07@gmail.com', henipujiastuti@untirta.ac.id²

DOI: http://dx.doi.org/10.15294/kreano.v1 1i1.22717

Received : December 27 2019; Accepted: April 13 2020; Published: June 12020

\begin{abstract}
Abstrak
Penelitian ini bertujuan untuk mendeskripsikan kemampuan komunikasi matematis siswa ditinjau dari self-concept. Penelitian ini merupakan jenis penelitian deskriptif dengan pendekatan kuantitatif. Subjek pada penelitian ini berjumlah 9 peserta didik kelas VIII MTs Al Ulya Al Mubarok. Instrumen yang digunakan dalam penelitian ini adalah tes kemampuan komunikasi matemtis dan angket self-concept serta wawancara. Hasill penelitian diperoleh siswa yang memimiliki self-concept tinggi mendapatkan hasil tes kemampuan komunikasi matematisnya kategori baik dengan persentase nilai $75 \%$ sebanyak 3 orang. Siswa yang memiliki self-concept sedang yaitu mendapatkan hasil tes kemampuan komunikasi matematis yang cukup yaitu dengan rentang persentase nilai 41\%-60\% sebanyak 4 orang, dan siswa yang memimiliki self-concept rendah hasil tes kemampuan komunikasi matematisnya kurang yaitu persentase nilainya $40 \%$ sebanyak 2 orang. Kemampuan komunikasi matematis siswa sejalan dengan selfconcept nya. Semakin tinggi self-concept siswa semakin baik pula kemampuan komunikasi matematisnya.
\end{abstract}

Kata Kunci: kemampuan komunikasi matematis; self-concept

\begin{abstract}
This study was designed to describe students' mathematical communication skills in terms of self-concept. This research is a type of descriptive quantitative research. The subjects in this study tested 9 students of class VIII MTs Al Ulya Al Mubarok. The instruments used in this study were tests of mathematical communication skills and self-concept questionnaires and interviews. The results of the study obtained that students who have high self-concept get mathematical communication skills test results in both categories with a percentage of $75 \%$ as many as 3 peoples. Students who have self-concept are getting sufficient mathematical communication test results with a range of $41 \%-60 \%$ assessment value as many as 3 peoples, and students who have low self-concept of mathematical communication skills test results are less that is beneficial value of $40 \%$ by 3 peoples. Students' mathematical communication skills are in line with their self-concept. The higher the student's self-concept the better his mathematical communication skills.
\end{abstract}

Keywords: mathematical communication; self-concept

\section{PENDAHULUAN}

Pendidikan memiliki peran yang sangat besar dalam usaha meningkatkan sumber daya manusia bagi bangsa Indonesia. Melalui sektor pendidikan ini peserta didik dibekali kemampuan untuk mengembangkan ke- mampuannya. Oleh karenanya, pendidikan yang senantiasa berkembang sejalan dengan perkembangan ilmu pengetahuan dan teknologi harus diimplementasikan agar mampu menghasilkan peserta didik yang mampu bersaing di dunia pendidikan secara regional maupun global. 
Di Indonesia, kualitas pendidikannya masih harus ditingkatkan dari apa yang telah dicapai sampai saat ini. Berdasarkan hasil penelitian PISA (Programme for International Student Assesment) yang digagas oleh OECD (Organization for Economic Cooperation and Development). Kepala Badan Penelitian dan Pengembangan (Balitbang) Kemdikbud, Totok Suprayitno, menyampaikan bahwa peningkatan capaian Indonesia tahun 2015 CUkup memberikan optimisme, meskipun masih rendah dibanding rerata OECD (Kemendikbud, 2014).

Berkaitan dengan hasil penelitian PISA kemampuan matematika menjadi salah satu faktor penting dalam meningkatkan mutu pendidikan. Matematika merupakan ilmu universal yang mendasari perkembangan teknologi modern, mempunyai peran penting dalam berbagai disiplin dan memajukan daya pikir manusia. Negara yang mengabaikan pendidikan matematika sebagai prioritas utama akan tertinggal dari kemajuan segala bidang, terutama sains dan teknologi (Johar, R., \& Ikhsan, M., 2014).

Mutu pendidikan suatu Negara dapat dilihat dari ketercapaian pengetahuan dan keterampilan siswanya. Identifikasi ketercapaian pengetahuan dan keterampilan siswa sekolah menengah dapat dilihat dari empat kategori menurut Ontorio Ministry of Educations (2005) yaitu (1) pengetahuan dan keterampilan, (2) berfikir, (3) mengkomunikasikan, (4) mengaplikasikan.

Hal ini sejalan dengan tujuan pembelajaran matematika yang ditetapkan kurikulum 2013 yaitu agar siswa mampu: (1) memehami konsep matematika (2) menggunakan pola sebagian dugaan dalam menyelesaikan masalah, (3) memahami masalah, membangun model matematika, meneyelesaikan model dan menafsirkan solusi yang diperoleh serta memecahkan masalah dalam kehidupan sehari-hari (4) mengkomunikasian gagagsan, penalaran dengan menggunakan kalimat lengkap, simbol, tabel, diagram atau media lain, (5) memilihi sikap menghargai kegunaan matematika dalam kehidupan, (6) memiliki sikap dan perilaku yang sesuai dengan nilai- nilai dalam matematika dan pembelajarannya, (7) melakukan kegiatan motorik yang meng- gunakan pengetahuan matematis. (8) menggunakan alat peraga sederhan (Permendikbud No 58, 2014).

Dari kedelapan tujuan pembelajaran matematika yang ditetapkan kurikulum 2013 salah satu diantaranya adalah tentang mengkomunikasikan gagasan. Menurut Clark (2005), kemampuan komunikasi siswa telah terlihat saat memasuki sekolah menengah, tidak hanya pada bidang bahasa dan sosial. Dalam hal ini tentunya matematika merupakan bidang yang dapat memperlihatkan kemampuan siswa dari proses pembelajarannya maupun dari hasilnya.

Sejalan dengan hal tersebut Nurul et al (2019), mengungkapkan pentingnya komunikasi karena beberapa hal yaitu untuk menyatakan ide melalui percakapan, tulisan, demonstrasi, dan melukiskan secara visual dalam tipe yang berbeda; memahami, menginterpretasikan dan mengevaluasi ide yang disajikan dalam tulisan atau dalam bentuk visual; mengkonstruksi, menginterpretasi, dan mengaitkan berbagai bentuk representasi ide dan berhubungannya; membuat pengamatan dan konjektur, merumuskan pertanyaan, membawa dan mengevaluasi informasi; serta menghasilkan dan menyatakan argumen secara persuasif.

Hal ini sejalan dengan yang diungkapkan oleh Nührenbörger, M., \& Steinbring (2009), yang menyatakan bahwa komunikasi dengan siswa dapat meningkatkan pengetahuan matematika siswa dan dengan proses refleksi menunjukan bahwa guru dapat memberikan impuls kepada siswa untuk dapat berbicara terbuka tentang matematika.

Sementara itu Sumarmo (2014), menjelaskan kegiatan yang tergolong pada komunikasi matematis di antaranya adalah: (a) Menyatakan situasi matematika atau peristiwa sehari-hari ke dalam model matematika; (b) Menyatakan model matematika (gambar, ekspresi aljabar) ke dalam bahasa biasa (menyusun soal cerita); (c) Memberi penjelasan terhadap model metematika atau pola; (d) Menyusun pertanyaan terhadap situasi yang diberikan disertai alasan.

Shadiq (2004), menyatakan pentingnya siswa belajar matematika dengan alasan bah- 
wa matematika merupakan alat komunikasi yang sangat kuat dan berpengaruh (powerful), teliti dan tepat (concise), serta tidak membingungkan (unambiguous). Pertiwi (2014) juga berpendapat matematika sarat akan lambang dan simbol dimana dibutuhkan pemahaman matematis yang tinggi untuk memahaminya. untuk meningkatkan pemahaman konseptual matematis yaitu dengan mengemukakan ide-ide matematisnya kepada orang lain. Kemampuan mengemukakan ide-ide matematis kepada orang lain baik secara lisan maupun tertulis tersebut dinamakan kemampuan komunikasi matematis. Komunikasi matematis siswa merupakan kemampuan berpikir tingkat tinggi yang harus selalu dikembangkan oleh siswa (Noor, 2018).

Kemampuan komunikasi mate-matis siswa dipengaruhi beberapa faktor diantaranya dipengaruhi oleh aspek psikologis yang menunjang keberhasilan siswa dalam menyelesaikan tugas dengan baik. Keyakinan siswa terhadap kemampuan dirinya dalam belajar matematika, keyakinan diri ini erat kaitannya self-concept siswa. Self-concept siswa dalam pembelajaran matematik disebut self-concept matematis. self-concept matematis merupakan peristiwa persepsi siswa terhadap kompetensi matematis yang mereka miliki dan kepercayaan terhadap kemampuan diri mereka yang berkaitan dengan keberhasilan pembelajaran dibidang matematika.

Menurut pendapat para ahli, salah satu diantaranya Ayodele (2012), siswa yang memiliki self-concept yang positif, prestasi belajar matematikanya lebih baik. Dengan terbentuk dan tertanamnya konsep diri dalam diri siswa akan berpengaruh terhadap proses berfikir matematisnya termasuk kemampuan matematisnya. Indikator self-concept antara lain: (1) kemandirian dalam mempelajari matematika, siswa memaksimalkan potensi yang dimilikinya. (2) keyakinan dalam mengatasi masalah, siswa yakin dalam memberikan jawaban (3) rasa tanggung jawab terhadap diskusi, setiap anggota kelompok aktif berpendapat (4) keaktifan saat pembelajaran, siswa mendominasi pembelajaran.

Menurut Obilor (2011) bahwa terdapat hubungan yang spesifik antar self-concept dengan prestasi di sekolah, yang mana pres- tasi akademik berkaitan secara positif dengan self-concept akademik dan sangat berkaitan dengan area konten. Dengan komunikasi matematis yang baik siswa dapat belajar secara bermakna. Kemampuan komunikasi matematis baik secara verbal maupun komunkasi secara tertulis sangat penting dikuasai oleh siswa, karena untuk menyongsong kemajuan teknologi dan inovasi, serta untuk menyesuaikan diri dengan pendidikan yang mengusung perkembangan keterampilan di abad-21 yang termuat salah satu di dalamnya adalah kemampuan komunikasi matematis. Berdasarkan paparan tersebut, maka dalam artikel ini akan diuraikan analisis kemampuan komunikasi matematis siswa ditinjau dari selfconcept siswa.

\section{METODE}

Metode yang digunakan dalam penelitian ini adalah penelitian deskriptif dengan pendekatan kuantitatif. Penelitian ini bertujuan untuk menganalisis dan mendeskripsikan kemampuan komunikasi matematis ditinjau dari self-concept siswa pada materi koordinat cartesius. Subjek pada penelitian ini berjumlah 9 siswa kelas VIII Mts Al Ulya Al Mubarok.

Penelitian ini menggunakan dua jenis instrumen, yaitu instrumen tes dan non tes. Instrumen tes berupa tes kemampauan komunuikasi matematis, disusun berbentuk soal uraian (essay) sebanyak 5 soal, melalui tes uraian ini dapat menggambarkan kemampuan komunikasi matematis siswa berdasarkan indikatornya. Sedangkan instrument non tes berupa angket skala self-concept siswa serta wawancara.

Skala self-concept siswa diberikan untuk mengetahui penilaian siswa tentang konsep diri yang berhubungan dengan rasa tanggung jawab, kesukaan terhadap pelajaran matematika. Angket skala likert yang digunakan dengan interval 1-4, sangat setuju (SS), setuju (S), tidak setuju (TS), sangat tidak setuju (STS).

Pernyataan angket dibuat berdasarkan indikator self-concept yang digunakan. Tiap indikator dalam angket juga terdiri dari pernyataan positif dan pernyataan negatif. Sehingga siswa diharapkan lebih teliti dalam mengisi angket dan lebih berpeluang mengisis angket 
denga sejujur-jujurnya.angket ini merupakan modifikasi dari angket self-concept yang telah disusun oleh Sumarmo (2017).

Tabel 1. Kriteria Tingkatan Self-Concept Arikunto (2008)

\begin{tabular}{cc}
\hline Persentase & Kriteria \\
\hline $81 \%-100 \%$ & Tinggi \\
$61 \%-80 \%$ & Sedang \\
$41 \%-60 \%$ & Rendah \\
$21 \%-40 \%$ & Rendah sekali \\
\hline
\end{tabular}

Pemberian skor hasil tes kemampuan komunikasi matematis siswa didasarkan pada indikator yang akan dicapai. Selanjutnya skor keseluruhan siswa dikonversi dalam bentuk nilai skala (1-100) serta menafsirkan data sesuai kriteria pemahaman berdasarkan batasan tersebut tercantum pada:

Tabel 2. Kriteria Data

\begin{tabular}{cc}
\hline Persentase & Kriteria \\
\hline $81 \%-100 \%$ & Baik Sekali \\
$61 \%-80 \%$ & Baik \\
$41 \%-60 \%$ & Cukup \\
$21 \%-40 \%$ & Kurang \\
$0 \%-20 \%$ & Kurang Sekali \\
\hline
\end{tabular}

\section{HASIL DAN PEMBAHASAN}

Hasil data yang diperoleh dari penyebaran angket self-concept terhadap 9 siswa di Kelas VIII MTs AI Ulya Al Mubarok, data yang diperoleh dari keseluruhan dapat melihat tingkatan self-concept (tinggi, sedang, dan rendah). Hasil tingkatan self-concept diperoleh dengan skala likert.

Jika dilihat dari hasil angket self-concept dan tes kemampuan komunikasi matematis siswa, siswa yang memiliki self-concept tinggi untuk nilai tes kemampuan komunikasi matematisnya juga masuk kategori baik, untuk lebih jelas dapat dilihat pada tabel berikut ini:

Tabel 3. Data Hasil Tes Kemampuan Komunikasi pada Siswa yang Memiliki Self-Concept Tinggi

\begin{tabular}{ccc}
\hline Tingkatan & Kode & Presentase Nilai \\
Self concept & Subjek & \\
\hline \multirow{2}{*}{ Tinggi } & S-4 & $75 \%$ \\
& S-6 & $75 \%$ \\
& S-7 & $75 \%$ \\
\hline
\end{tabular}

Siswa yang yang memiliki self-concept yang tinggi dengan kode Subjek S-4, S-6, S-7 mendapatkan hasil yang baik juga dalam tes kemampuan komunukasi matematisnya, yaitu masuk kategori baik dengan presentasi nilai $75 \%$. Hasil temuan ini didukung oleh pendapat dari (Andinny, 2015). Yang menyatakan bahwa siswa yang mempunyai kemampuan self-concept yang positif akan mempunyai kemampuan untuk menyesuaiakan diri lebih baik, dapat mempengaruhi situasi yang dimiliki dengan lebih baik serta dapat menghindari diri dari reaksi negatif, dan dapat menunjukkan kemampuan kognitif.

Pada penelitian ini kemampuan kognitifnya adalah kemampuan komunikasi matematis. Hal ini juga sejalan dengan hasil penelitian Mekarina (2018) yang menyatakan bahwa Self-Concept positif berpengaruh terhadap kemampuan komunikasi serta koneksi matematis siswa, dengan konsep diri positif akan terlihat optimis, penuh percaya diri dan cenderung bersikap positif terhadap sesuatu.

Hal tersebut juga didukung penelitian Hanifah (2019) menyatakan seseorang dengan konsep diri negatif akan terlihat lebih pesimis, menganggap dirinya tidak berdaya, merasa tidak disenangi dan tidak diperhatikan. Dengan demikian, siswa dengan konsep diri negatif akan cenderung bersikap pesimistik terhadap kemampuannya pada masalahmasalah matematika dan mudah menyerah dalam menghadapi masalah-masalah matematika. Dengan demikian, konsep diri negatif dapat dimungkinkan berpengaruh buruk terhadap prestasi belajar matematika. Dan sebaliknya konsep diri positif dapat meningkatkan kemampuan kognitifnya, dalam hal ini kemampuan komunikasi matematisnya. Didukung juga dari hasil wawancara terhadap siswa yang mendapat skor hasil angketnya memiliki self-concept tinggi yang menyatakan bahwa mereka dalam pembelajaran dapat bekerja sama, saling toleran terhadap temannya ketika mengerjakan soal matematika. Dan mereka menyukai pembelajaran matematika. Ketika melihat soal yang kompleks mereka tertantang untuk menyelesaikannya. 


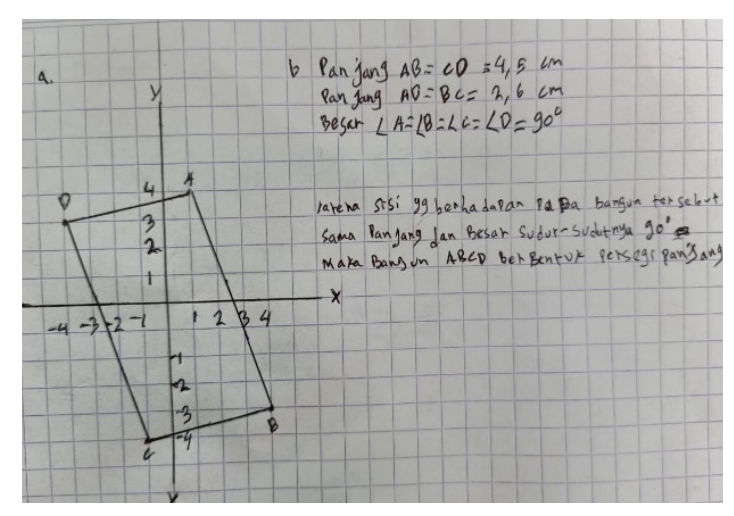

Gambar 1. Jawaban Tes Kemampuan Komunukasi Matematis Siswa yang Memiliki Self-Concept Tinggi.

Dari hasil jawaban salah satu siswa yang nemiliki self-concept tinggi hasil tes kemampuan komunikasinya juga baik, siswa dapat memberikan jawaban sesuai dengan indikator kemampuan komunuikasi matematis, yaitu siswa dapat menyatakan model matematika (gambar, ekspresi aljabar) ke dalam bahasa biasa, memberi penjelasan terhadap model metematika atau pola.

Tabel 4. Data Hasil Tes Kemampuan Komunikasi pada Siswa yang Memiliki Self-concept Sedang

\begin{tabular}{ccc}
\hline $\begin{array}{c}\text { Tingkatan } \\
\text { Self concept }\end{array}$ & Kode Subjek & $\begin{array}{c}\text { Presentase } \\
\text { Nilai }\end{array}$ \\
\hline Sedang & S -2 & $60 \%$ \\
& S-5 & $55 \%$ \\
& S-9 & $55 \%$ \\
& S-1 & $45 \%$ \\
\hline
\end{tabular}

Siswa yang memiliki self-concept sedang untuk hasil tes kemampuan komunikasi matematisnya masuk kategori cukup, diantaraya subjek dengan kode $\mathrm{S}-2$ yang presentase nilainya $60 \%$, subjek S- 5 dan S-9 yang presetase nilainya $55 \%$, serta S-1 $45 \%$.

Ada banyak faktor yang mempengaruhi self concept, menurut Leonard dan Supardi (2010) menjelaskan bahwa "konsep diri bukan merupakan faktor yang dibawa sejak lahir, melainkan faktor yang dijiwai dan terbentuk melalui pengalaman individu dalam berhubungan dengan orang lain.

Untuk subjek yang self- conceptnya sudah baik tetapi masih kurang kemapuan komunikasi matematisnya, harus perlu diasah dengan berada di lingkungan yang baik, se- moga akan menjadi motivasi untuk lebih baik dalam aspek kognitifnya.

Dibawah ini merupakan salah satu contoh jawaban siswa yang memiliki self-concept sedang. Komunikasi matematisnya cukup dan self-conceptnya berada pada level sedang, terlihat bahwa hasilnya belum memberi penjelasan terhadap model metematika atau pola gambar, serta memberikan alasannya.

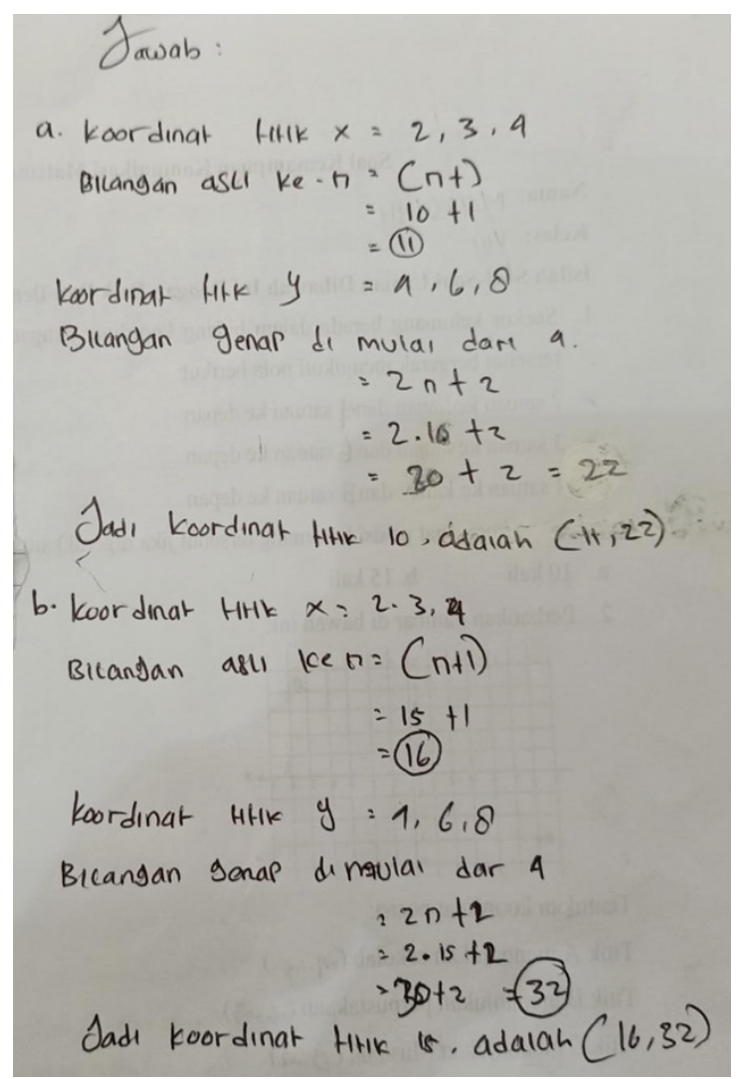

Gambar 2. Jawaban Tes Kemampuan Komunukasi Matematis Siswa yang Memiliki Self-Concept Sedang

Dibawah ini merupakan hasil dari subjek yang memiliki self-concept rendah, serta kemampuan komunikasi matematisnya yang kurang.

Tabel 5. Data Hasil Tes Kemampuan Komunikasi pada Siswa yang Memiliki Self-Concept Rendah

\begin{tabular}{ccc}
\hline $\begin{array}{c}\text { Tingkatan } \\
\text { Selfconcept }\end{array}$ & Kode Subjek & $\begin{array}{c}\text { Presentase } \\
\text { Nilai }\end{array}$ \\
\hline Rendah & S- 3 & $40 \%$ \\
& S- 8 & $40 \%$ \\
\hline
\end{tabular}

Hasil dari angket self-concept yang memiliki self-concept rendah yaitu subjek dengan 
kode S-3, dan S-8. Tes kemampuan komunikasi matematis siswanya memiliki presentase yang kurang. Siswa S-8 belum bisa menyatakan peristiwa sehari-hari dalam bahasa atau simbol matematika, belum bisa menyimpulkan sesuai dengan permasalahan awal secara lengkap dan tidak melakukan pemeriksaan kembali jawabannya. Ini sejalan dengan penelitian yang dilakukan oleh dilakukan oleh Widiarti (2017) bahwa konsep diri yang cenderung rendah atau negatif merupakan konsep diri yang meliputi etik, moral, sosial dan personal diperlukan pendampingan dengan pendekatan tertentu untuk dapat menyampaikan komunikasinya.

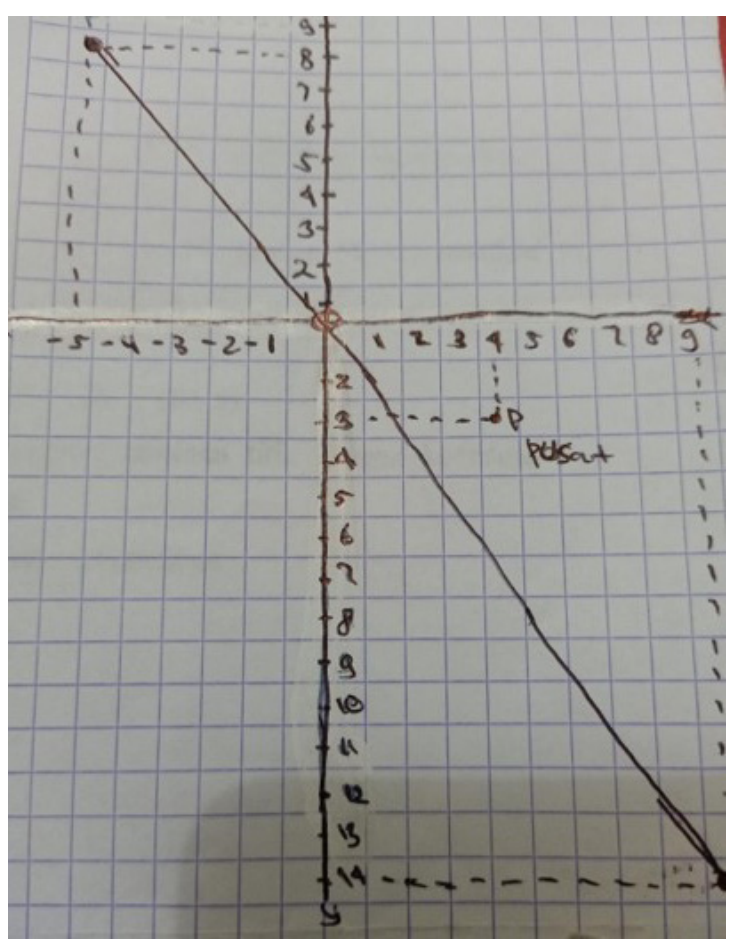

Gambar 3. Jawaban Tes Kemampuan Komunukasi Matematis Siswa yang Memiliki Self-Concept Rendah

Dari hasil jawaban siswa yang masih memiliki kemampuan komunikasi matematis rendah, jawabannya masih belum lengkap, terjadi kesalahan dalam membuat titik potong yang diharapkan, jawabannya tidak terstruktur. Seseorang yang memiliki self-concept yang negatif atau kita sebut dengan selfconcept rendah dalam hal ini, ditandai dengan individu bersikap pesimis terhadap kompetisi, keenggannannya untuk bersaing dengan yang lain yang membuat seseorang tidak berprestasi dalam bidang akademik. Dalam penelitian ini kajian kognitif yang dianalisisnya adalah kemampuan komunikasi matematisnya.

\section{PENUTUP}

Berdasarkan hasil dan pembahasan, diperoleh simpulan, siswa yang memiliki self-concept tinggi yaitu S4, S-6, dan S-7 mendapatkan hasil kemampuan komunikasi matematisnya kategori baik yaitu dengan persentase nilai $75 \%$. Siswa yang memimiliki self-concept sedang yaitu S-1, S-2, S-5 dan S-9 mendapatkan hasil kemampuan komunikasi matematis yang cukup yaitu dengan rentang persentase nilai 41\%-60\%, untuk siswa yang memimiliki self-concept rendah S-3 dan S-8 hasil tes kemampuan komunikasi matematis yang kurang yaitu $40 \%$. Jadi kemampuan komunikasi matematis siswa sejalan dengan self conceptnya. Semakin tinggi self-concept siswa semakin baik pula kemampuan komunikasi matematisnya.

\section{DAFTAR PUSTAKA}

Andinny, Y. (2015). Pengaruh Konsep Diri dan Berpikir Positif terhadap Prestasi Belajar Matematika Siswa. Formatif: Jurnal Ilmiah Pendidikan MIPA, 3(2), 126-135.

Arikunto, S. (2008). Penelitian Tindakan Kelas. Jakarta: Bumi Aksara

Ayodele, O. J. (2011). Self-concept and performance of secondary school students in mathematics. Journal of Educational and Developmental Psychology, $1(1), 176-183$.

Clark, K. K., Jacobs, J., Pittman, M. E., \& Borko, H. (2005). Strategies for Building Mathematical Communication in The Middle School Classroom: Modeled in Professional Development, Implemented in The Classroom. Current Issues in Middle Level Education, 11 (2), 1-12.

Hanifah. (2019). Hubungan antara konsp diri dengan prestasi akademik mahasiswa pada mata kuliah teori grup. Kreano, Jurnal Matematika KreatifInovatif, 10(2), 141-145

Johar, R., \& Ikhsan, M. (2014). Peningkatan Kemampuan Pemecahan Masalah dan Komunikasi Matematis Siswa SMP melalui Model Pembelajaran Meansends Analysis. Kreano, Jurnal Matematika Kreatif-Inovatif, 5(2), 105-113.

Kemendikbud. (2014). Peraturan Menteri Pendidikan Dan Kebudayaan (Pertiwi \& Susilo, 2014)Nomor 58 Tahun 2014 Tentang Kerangka Dasar Dan Struktur Kurikulum Sekolah Menengah Pertama/Madrasah Tsanawiyah. Jakarta: Kemendikbud.

Leonard dan Supardi U.S. (2010). Pengaruh konsep diri, 
sikap siswa pada matematika, dan kecemasan siswa terhadap hasil belajar matematika. Cakrawala Pendidikan, 29 (3): 341-353.

Nührenbörger, M., \& Steinbring, H. (2009). Forms of mathematical interaction in different social settings: examples from students', teachers' and teacher-students' communication about mathematics. Journal of Mathematics Teacher Education, 12(2), 111-132.

Mekarina. (2018). Peningkatan Kemampuan Koneksi dan Komunikasi Matematis Serta Self-Concept siswa memalui Model Brain Base [DOCTORAL DISSERTATION]. Bandung: Universitas Pendidikan Indonesia

Noor, F. (2018). Kemampuan berpikir Kritis Dan komunikasi Matematis siswa smp Dalam Pembelajaran problem Posing berbasis Kearifan Lokal Kalimantan Selatan. Math Didactic: Jurnal Pendidikan matematika, 4(3), 226-234

Noviyanti, S. (2014). Penerapan Pembelajaran Missouri Mathematics Project pada Pencapaian Kemampuan Komunikasi Lisan Matematis Siswa Kelas VIII. Kreano: Jurnal Matematika Kreatif-Inovatif, 5(2), 211-218.

Nurul, N., Octaviani, A., \& Zanthy, L. S. (2019). Analisis Kemampuan Koneksi Dan Komunikasi Matematis Ditinjau Dari Kepercayaan Diri Siswa SMP.
JPMI (Jurnal Pembelajaran Matematika Inovatif), 2(2), 57-64.

Obilor, I. E. (2011). Interaction between self-concept, and mathematics, English language and general academic achievement of senior secondary students in Port Harcourt. Journal of Educational and Social Research, 1(4), 39-46.

Ontario Ministry Education .(2005). Capacity building series secretariat special edition in 2010. Claifornia. Ontorio development, implemented in the classroom. Current Issue In Middle Level Education, 11(2), 1-12

Pertiwi, A.D., \& Susilo, B.E. (2014). Analisis Kemampuan Komunikasi Matematis Melalui Pembelajaran Model $4 \mathrm{~K}$ Berdasarkan Tipe Kepribadian Peserta Didik Kelas VII. Kreano: Jurnal Matematika Kreatif-Inovatif, 5(2), 195-204.

Shadiq, F. (2004). Pemecahan masalah, penalaran dan komunikasi. Yogyakarta: PPPG Matematika.

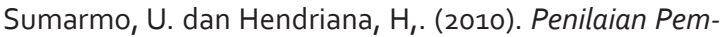
belajaran Matematika. Bandung: Refika Aditama.

Widiarti, W.P. (2017). Konsep Diri (Self Concept) dan Komunkasi Interpersonal dalam Pendampingan pada Siswa SMP Se Kota Yogyakarta, Informasi, $47(1), 135-148$. 